\title{
Trading Activity as a Liquidity Measure In Indonesia Stock Exchange
}

\author{
Erna Garnia \\ Sangga Buana YPKP University \\ Bandung, Indonesia
}

\author{
Rachmat Sudarsono, Dian Masyita, and Ina Primiana \\ Padjadjaran University \\ Bandung, Indonesia
}

\begin{abstract}
Trading activity that is indicated by the trading volume or the turnover is the measures of stock market liquidity. This paper presents a theoretical and empirical investigation of the relation between return and trading activity. As a consequence of clientele effect that relating the holding period and bid-ask spread, this paper shows that relation between return per unit price per unit time and trading activity, has a concave form similar as the relation between return per unit price per unit time and bid-ask spread. Based on the monthly data from Indonesia Stock Exchange for the period of 2008-2013, the proposed concept has been validated.
\end{abstract}

Key words: trading activity, liquidity, clientele effect

\section{INTRODUCTION}

Liquidity has been considered as a new investment style that is very important in asset pricing [1]. Though it cannot be defined exactly, liquidity can be simply stated as how fast and how much cost to liquidate a stock or an asset. Thus most important parameters of liquidity are the liquidity level and uncertainty of that level, i.e. liquidity risk. For the measures of liquidity, various measures have been used such as bid-ask spread, trading activity and resiliency. Trading activity is usually indicated by the trading volume or the turnover.

Amihud and Mendelson have shown theoretically and empirically the relation between return and bid-ask spread [2]. The work had also shown that holding period is linearly proportional to the bid-ask spread (clientele effect). As consequence of the clientele effect, the relation between return and bid-ask spread has a concave form. Since this work, a lot of works on liquidity adjusted capital asset pricing model were published.

Many works had published on the relation between return and trading activity. Chordia et al. have shown that trading activity has negative effect on the return [3]. However, Campbell has shown an opposite result that is the trading activity has a positive effect on the return [4]. The result of Campbell has been supported by Chan and Faff, who find that the trading activity is positively affecting the return [5]. As far as authors are aware there are no works have explained why there are contradictory results.

This paper presents a theoretical and empirical investigation of the relation between return and trading activity. As a consequence of clientele effect that relating the holding period and bid-ask spread, this paper shows that relation between return and trading activity, has a concave form similar as the relation between return and bid-ask spread. Based on the monthly data from Indonesia Stock Exchange for the period of 2008-2013, the proposed concept has been validated.

\section{REVIEW OF PREVIOUS WORKS}

Liquidity is an elusive concept that is difficult to define exactly but can be simply stated as how fast and how much the cost to exchange stocks or assets [6]. Based on that definition, stock liquidity can be measured by transaction cost or liquidation cost, trading activity and resiliency. Transaction cost includes ordering cost, holding cost, adverse selection cost and any applicable taxes. Trading activity is usually measured by trading volume and turnover. Resiliency is an indication how the price is affected by the trading volume.

Though the effects of liquidity on asset pricing have been investigated since a long time ago, Amihud and Mendelson are the first that formulating theoretically the relation between return and liquidation cost [2]. The liquidation cost is measured by the relative bid-ask spread. First they show that the stock holding period is positively affected by the bid-ask spread (clientele effect). Thus an investor must hold a stock longer to compensate the higher liquidation cost. As a consequence of clientele effect, they show that the relation between return and bid-ask spread has a concave form. Amihud also has proposed another liquidity measure that is price impact (resiliency) which measures how the trading volume is affecting the stock price [7]. That paper has shown the positive relation between return and this new illiquidity measure. This concept has been proved at several kinds of securities and also several security markets [8].

Many works on the relation between stock return and trading activity were published. A negative relation between trading volume and stock return has been found [3]. However, an opposite result has also been reported [4]-[5]. There are many works using stock turnover as a measure of trading activity, e.g. [9]-[10]. They have also shown that turnover is priced by the investors. Though a lot of works on the relation between stock return and trading activity are still published until recently [11]-[12], as far as authors are aware, there are no works have explained why there are contradictory results.

Many works have been done in Indonesia Stock Exchange. Febrian and Herwany used GARCH to show bid-ask spread, trading frequency and ratio illiquidity as liquidity measures at Indonesia Stock Exchanges [13]. Madyan et al. were worked at liquidity determinants of sharia and non-sharia stocks. Based on 2009-2010 data, they didn't find the difference of liquidity determinant between sharia and non-sharia stocks [14]. 


\section{THEORETICAL CONCEPT}

In one holding period, an investor should receive an income that is higher than the liquidation cost. By using the same assumption as Amihud and Mendelson [2], the following relation is obtained:

$$
D \times T=C \times P
$$

where $D$ is perpetual cash flow that may represents dividend and/or capital gain per unit time (Rupiah per unit time), $T$ is holding period, $C$ is liquidation cost per unit price, and $P$ is the stock price. Liquidation costs include ordering cost, holding cost and any other indirect cost. The exact liquidation cost is unknown but usually can be represented by the bid-ask spread [15]. This is reasonable because bidask spread represents pressure to buy or pressure to sell, asymmetrical information and any frictions in the market. Equation (1) can also be written as

$$
d \times T=C
$$

where $d=D / P$ is the return per unit price per unit time. Equation (2) shows clearly that if the return per unit price per unit time is constant then the holding period is linearly proportional to the liquidation cost (clientele effect).

Based on the work of Atkins and Dyl [16], the average holding period of stocks can be estimated by

$$
T=\frac{O s}{V o l}
$$

where $O s$ is the stock outstanding share and $\mathrm{Vol}$ is the stock trading volume per unit time. If (3) is substituted into (2) then the following equation is obtained

$$
d \times \frac{O s}{V o l}=C
$$

Equation (4) shows that under constant return per unit price per unit time, the trading volume is inversely proportional to the liquidation cost. Thus, higher liquidation cost induces lower trading volume. Equation (4) can also be written as

$$
d=C \times \frac{V o l}{O s}
$$

Equation (5) shows clearly that under constant trading volume, the return is linearly proportional to the liquidation cost. Thus higher liquidation cost must be compensated by higher return. However, as higher liquidation cost induces lower trading volume, the effect of liquidation cost on the return will be reduced when the liquidation cost is increased. If the rate of decrease of trading volume is much faster than the increase of liquidation cost, the total effects on the return may look like negative. This is the reason why some researches reporting contradictory results. Similarly, (5) shows clearly that under constant liquidation cost, the stock return is linearly proportional to the trading volume. However as higher trading volume induce lower liquidation cost, the effect of trading volume will be reduced when the trading volume is higher (concave form). If the rate of decrease of liquidation cost is much faster than the increase of trading volume, the total effects on the return may look like negative.

\section{EMPIRICAL RESULTS}

This paper use monthly data of 2008-2013 from Indonesia Stock Exchanges. We have just included companies that doing no corporate actions during the observation period. There are 52 companies satisfying the criterion. Based on that data, the monthly average in five years period has been calculated that is average of returns, average of trading volumes, and average of bid-ask spreads. The return used here is the net excess return.

Based on (4), trading volume is inversely proportional to the liquidation cost or bid-ask spread. Equation (4) also says that the holding period, that is the ratio of outstanding share to the trading volume, is proportional to the bid-ask spread (clientele effect). It means that higher (lower) bid-ask spread induces lower (higher) trading volume. Fig. 1 shows the plot that relating the trading volume and relative bid-ask spread for the 52 companies during the observation period. As the outstanding share is constant, this figure clearly shows that $1 / \mathrm{Vol}$ is linearly proportional to the bid-ask spread.

Based on (5), trading volume has positive impact to the return per unit price per unit time. Under constant bid-ask spread then return per unit price per unit time linearly proportional to the trading volume. As clientele effect consequence, however, bid-ask spread decrease while trading volume increase. It means that the slope which relating return per unit price per unit time and trading volume is decrease with increasing of trading volume (concave). Fig. 2 shows the relation between return per unit price per unit time and trading volume. This figure shows that the trading volume has a positive effect on the net return when the trading volume is not so high (less than 200 million shares per month). For higher trading volumes, however, the figure shows that the trading volume has a negative effect on the net return. Fig. 2 clearly shows that the relation between return per unit price per unit time and trading volume has a concave form as the proposed concept. Non-zero intercept indicates that there are some factors that affecting the return. These factors can be market risk $(\beta)$ and size as already indicated by Amihud and Mendelson [2].

The relation between return per unit price per unit time and turnover has a similar result with the trading volume that is linearly proportional to the return per unit price per unit time and has a concave form. Trading volume and turnover have the same meaning under constant outstanding share.

Fig. 2 shows that the effect of trading volume on the return can be positive or negative depending on the market conditions. This result looks contradictory with the intuition that higher trading volume, that is more liquid, should result in

the lower return. This intuition is correct if the liquidation cost is reduced very fast when the trading volume is increased.

In general, however, trading volume has a positive impact on the return per unit price per unit time. It should be noted that higher trading volume means frequent- liquidation cost must be paid by investors in the market. Thus, the stock must generates income to compensate that liquidation cost.

\section{CONCLUSION}

The relation between return and trading activity has been theoretically and empirically clarified. As consequence of clientele effect, the works shows that bid-ask spread has a negative impact to the trading volume and positive impact to the return. Clientele effect has made the relation between return per unit price per unit time and trading activity has a concave form as same as the relation between return per unit price per unit time and bid-ask price. 


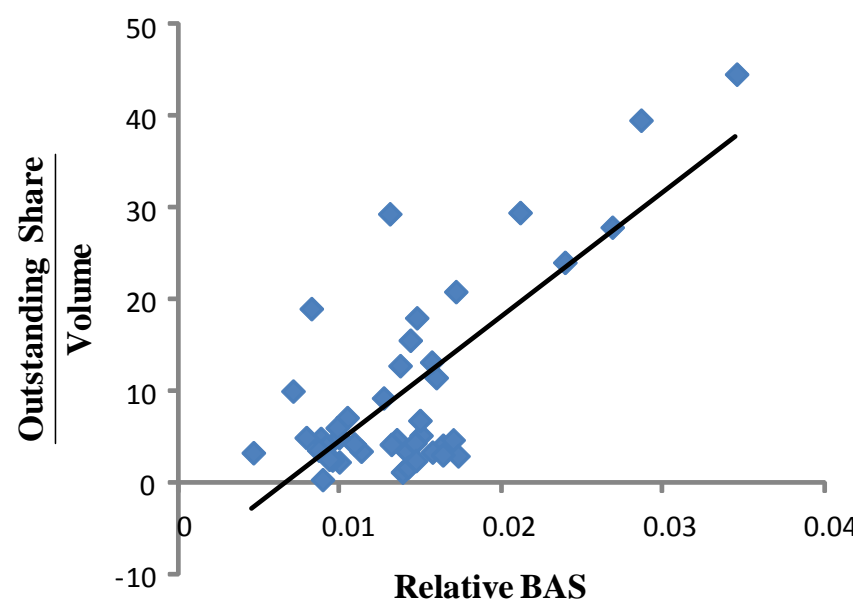

Fig. 1. Relationship between trading volume and bid-ask spread.

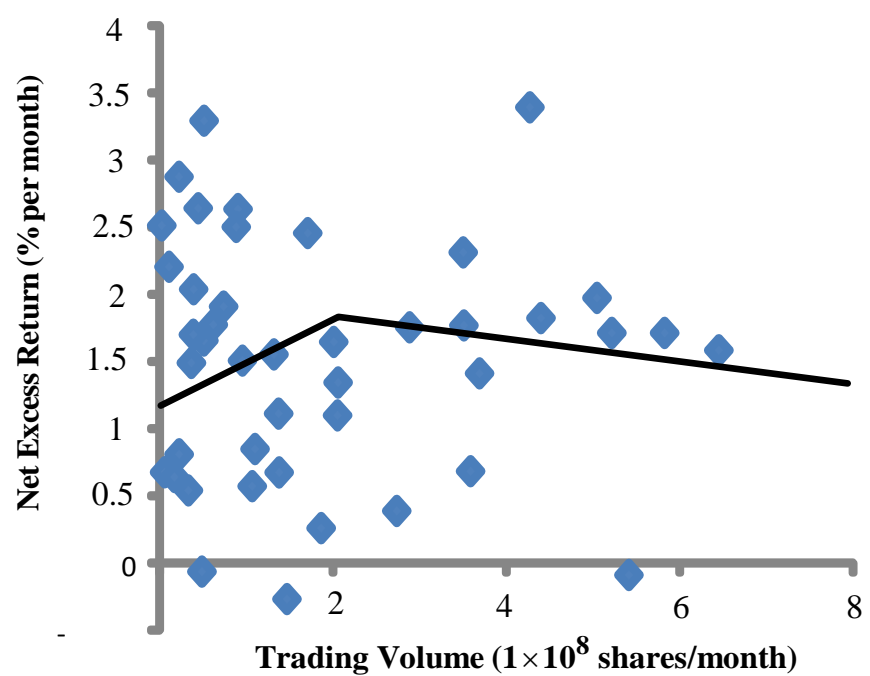

Fig. 2. Relationship between monthly return and trading volume.

\section{References}

[1] Ibbotson R.G., and Kim D.Y.Z, "Liquidity as an Investment Style", Financial Analyst Journal, vol. 69, No 3, pp. 30-44, 2015.

[2] Amihud, Y., and Mendelson, H., "Asset pricing and the bid-ask spread". Journal of Financial Economics, vol. 17, pp. 223-249, 1986.

[3] Chordia, T., Subrahmanyam, A., and Anshuman, V.R., "Trading activity and expected stock returns", Journal of Financial Economics, vol. 59, pp 3-32, 2001.

[4] Campbell, J.Y., Grossman, S.J, Wang, J., "Trading Volume and Serial Correlation in Stock Returns", The Quarterly Journal of Economics, pp. 905-939, 1993

[5] Chan, H.W. and Faff, R.W., "An investigation into the role of liquidity in asset pricing: Australian evidence", Pacific-Basin Finance Journal, vol. 11, pp 555-572, 2003.

[6] Amihud, Y., Mendelson, H., Pedersen, L. H., "Liquidity and Asset Prices", Foundation and Trends in Finance, vol. 1, No. 4, pp. 269$364,2005$.

[7] Amihud, Y., "Illiquidity and stock returns: cross-section and time series effect”. Journal of Financial Market, vol. 5 pp. 31-56, 2002.
[8] Amihud, Y., Mendelson., H., and Pedersen, L.H. ,"Market Liquidity : Asset Pricing, Risk, and Crises", Cambridge University Press, 2013.

[9] Datar, V.T., Naik N. Y., and Radcliffe, R., "Liquidity and stock returns: An alternative test", Journals of Financial Markets, vol. 1, pp. 203-129, 1998

[10] Liu, W., "A Liquidity-augmented Capital Asset Pricing Model", Journal of Financial Economics, vol. 82, pp. 631-671, 2006.

[11] Chordia, T., Subrahmanyam, A., and Tong, Q., "Have capital market anomalies attenuated in the recent era of high liquidity and trading activity?", Journal of Accounting and Economics, vol. 58, pp. 41-58 2014.

[12] Kinnunen, J., "Risk-return trade-off and serial correlation: Do volume and volatility matter?," Journal of Financial Markets, vol. 20, pp. 119,2014

[13] Febrian, E., and Herwany, A., "Liquidity Measurement Based on Bid-ask Spread, Trading Frequency, and Liquidity Ratio: The use of GARCH Model on Jakarta Stock Exchange (JSX)", Working Papers in Business, Management and Finance LMFE Unpad,, No 20100, pp. $1-14,2010$.

[14] Madyan, M., Salim, U., Anshori, M., Solimun, "Liquidity Determinants of Sharia and non-Sharia Stocks" IOSR Journal of Business and Management (IOSR-JBM), vol. 9, pp 28-38, 2013.

[15] Demsetz, H., "The Cost of Transacting", Quarterly Journal of Economics, pp. 33-53, 1968.

[16] Atkins, A. and Dyl, E., "Transaction Costs and Holding Periods for Common stocks", The Journal of Finance, vol. 52, No 1 pp. 309-325, 1997. 